\title{
Health warnings on cigarette packages and interest in quitting: findings from five countries conducted the Global Adult Tobacco Survey in 2011-2012
}

\author{
Guat Hiong Tee ${ }^{1}$, Tahir Aris ${ }^{1}$, Mohd Azahdi Omar ${ }^{1}$, Muhammad Fadhli Mohd Yusoff ${ }^{1}$, James Rarick ${ }^{2}$, Chee Cheong Kee ${ }^{3}$ and Sorina Irimie ${ }^{4}$ \\ ${ }^{1}$ Institute for Public Health, National Institutes of Health, Ministry of Health Malaysia, Jalan Bangsar, 50590 Kuala Lumpur \\ ${ }^{2}$ Non-Communicable Disease, WHO Office, Phnom Penh, Cambodia \\ ${ }^{3}$ Institute for Medical Research, National Institutes of Health, Ministry of Health Malaysia, Jalan Pahang, 50588 Kuala Lumpur \\ ${ }^{4}$ National Institute of Public Health, Regional Centre of Public Health, Cluj, Romania
}

\begin{abstract}
This study examines findings from the Global Adult Tobacco Surveys in five countries: Argentina, Indonesia, Malaysia, Nigeria, and Romania in assessing the effects of health warnings (HWs) on cigarette packages and interest in quitting. This was a household survey using multistage cluster sample design. Data were collected from one respondent per household aged 15 years and above via interviewer-administered questionnaires. The impact of HWs within each gender were analyzed by age group and education level using bivariate analysis. Among current smokers, Romanian (98.0\%) and Malaysian (94.1\%) men, Romanian (97.6\%) and Argentina $(89.3 \%)$ women had the highest percentages of noticing health warnings on cigarette packages. However, less than $50 \%$ of men in all five countries and women in Indonesia, Romania and Argentina thought about quitting smoking. In addition, less than 50\% of men and women tried to quit smoking in the past 12 months. These analyses provide great opportunity for countries to assess the effectiveness of their health warnings in communicating the risk of smoking to all current smokers. Countries can use these evidence-based findings to target tobacco control interventions to increase quit rates among current smokers and prevent smoking initiation among non-smokers.
\end{abstract}

\section{Introduction}

Cigarette smoking, referred to as smoking from here forth, kills one out of two long-term users and is the second major cause of death globally; making tobacco consumption one of the most important public health issues for all nations in the world. If the epidemic is left unchecked, it could result in one billion deaths in the $21^{\text {st }}$ century [1]. In recognition of the health and economic burden from tobacco use, the World Health Organization (WHO) has identified health warnings (HWs) on cigarette packages as one of the six key measures to curb the tobacco epidemic [1]. A total of 176 countries have ratified the Framework Convention on Tobacco Control (FCTC), the first international treaty devoted to public health. The FCTC obligates ratifying countries to broaden comprehensive tobacco control policies, which includes the packaging and labelling of tobacco products. Article 11 of the FCTC states countries that ratify the FCTC are required to implement HWs describing harmful effects of smoking on cigarette packages that cover at least $30 \%$ of the surface and are "large, clear, visible, and legible". Beyond these minimum requirements, Article 11 of the FCTC also recommends that warnings "should" cover $50 \%$ or more of package's principal surface, and "may" be in the form of pictures [2].

HWs on cigarette packages have been increasingly used to inform and educate cigarette smokers, referred to as smokers from here forth, on the health consequences of smoking. Canada was the first country to implement graphic HWs on cigarette packages in December 2000 [3]. As of September 2014, 77 countries / jurisdictions have finalized and implemented picture warnings on cigarette packages [4]. Pictorial health warnings (PHWs) on cigarette packages depict the harm caused by smoking; including various types of cancers, heart diseases, stroke, various lung diseases, mouth disease, impotence and gangrene [5].

Many smokers are not fully aware of the risks of cigarette use to their health even though there is clear evidence of dangers of its use $[1,6]$. HWs on cigarette packages serve as an important means of communicating health risks of smoking not only to smokers but to non-smokers as well. HWs on cigarette packages have broad reach and provide information to smokers about the health consequences associated with smoking. They are extremely cost-effective (with virtually no cost to government) for public health intervention; a pack a day smokers are potentially exposed to HWs more than seven thousand times a year [3,7]. In addition, HWs on cigarette packages can also be seen by non-smokers, including family members, friends and co-workers. These individuals have reported high exposure and awareness of HWs on cigarette packages [8].

Effective and hard-hitting HW labels capture attention of smokers and provide to them strong health messages about the health effects

Correspondence to: Guat Hiong Tee, Institute for Public Health, National Institutes of Health, Ministry of Health Malaysia, Jalan Bangsar, 50590 Kuala Lumpur, Malaysia, Tel: +603-22979400; Fax: +603-22823114; E-mail: helentee. gh@moh.gov.my

Key words: health warnings, smoking, current smokers, cigarette packages, interest in quitting, Global Adult Tobacco Survey (GATS)

Received: July 03, 2017; Accepted: August 05, 2017; Published: August 08, 2017 
of smoking. These messages help to bring about behavioural changes, thus increase the likelihood of reducing or quitting smoking $[6,9]$. Health warnings, especially graphic HWs, have been widely reported as an effective mean to reduce smoking in more than 30 countries [10]. The ultimate aim of HWs on cigarette packages is to denormalize smoking; thus, reducing smoking and increasing support for tobacco control measures [1].

During 2011 to 2012, five countries completed the Global Adult Tobacco Survey (GATS): Argentina, Indonesia, Malaysia, Nigeria, and Romania. The aim of this paper is to present and compare the findings from these five countries on the effects of cigarette package HWs and quit attempts. At the time of the surveys, all five countries had warning labels on cigarette packages. However, only Romania [11] and Malaysia [4] had fully adopted PHWs on cigarette packages since 2008 and 2009 respectively. Argentina had not ratified the WHO FCTC; however it required PHWs in June 2012 when the data collection was underway [4]. Indonesia has recently adopted PHWs on cigarette packages in June 2014 [4]. Nigeria is the only country in our study that has not required $\mathrm{PHW}$ on cigarette packages even though there are textual warning labels [4].

\section{Materials and methods}

\section{Study design}

GATS is a nationally representative household survey using a multistage cluster sample design. Households were selected proportional to the size of population and data were weighted to be representative of the adult population aged 15 years or older. Data were collected from participants via interviewer-administered questionnaires using handheld computers in 2011-2012. Informed consents were obtained from participants before commencing interviews. All participating countries used a standardized sample design and core questionnaire with added optional questions if applicable to ensure consistent data collection for comparison in key tobacco control indicators across countries [12,13]. A detailed description of survey methodologies for each country is available in the respective country reports. Ethical review and approval were obtained from relevant institution(s) by the implementing agency(ies) in each country [11,13, 15-17].

\section{Measures}

Current smoking: In this study, current smoking referred to current smoking of manufactured cigarettes (including kreteks in Indonesia) only.

Demographic variables: Demographic variables included: gender (male / female), age group (15-24 years, 25-44 years, 45-64 years and $65+$ years) and level of education attained (less than primary, less than secondary, complete high school, and college or above).

Health warning measures and cessation: Current smokers were asked questions about their exposure and response to HWs and quit attempts. These were standard core questions of GATS [13].

Noticing health warnings: Noticing of HWs was assessed by using the question "In the last 30 days, did you notice any health warnings on cigarette packages?". Responses were "Yes", "No" and "Do not see any cigarette package". Respondents who answered "Yes" were considered to have noticed HWs on cigarette packages.

Thinking of quitting smoking because of health warnings: Thinking of quitting smoking because of HWs was assessed by the question "In the last 30 days, have health warning on cigarette packets made you think about quitting smoking?". Responses were "Yes", "No" and "Don't know". Respondents who answered "Yes" were considered to be thinking of quitting smoking.

Attempts to quit smoking: Attempts to quit smoking was assessed by the question "During the past 12 months, have you tried to stop smoking?". Responses were "Yes", "No" and "Don't know". Respondents who answered "Yes" were considered to have attempted to quit smoking.

\section{Statistical analysis}

The impact of HWs within each gender were analyzed by age group and education level using bivariate analysis. Data for women from Malaysia and Nigeria were excluded due to the small number of current smokers in these two countries. Differences in response estimates were considered statistically significant if $95 \%$ confidence intervals (CI) did not overlap [18]. All data analyses were conducted using SPSS version 18.0 for complex samples.

\section{Results}

Table 1 provides the prevalence rates of current smoking among men: $7.1 \%$ (CI 6.2-8.2) in Nigeria, 29.0\% (24.3-34.1) in Argentina, $37.1 \%$ (34.5-39.7) in Romania, 38.3\% (CI 35.1-41.7) in Malaysia, and 63.4\% (CI 60.7-66.0) in Indonesia. Among women, the prevalence varied greatly; ranging from $0.2 \%$ (CI $0.1-0.5$ ) to $16.7 \%$ (CI 15.1-18.5) among Nigerians and Romanians respectively. The prevalence of current smoking was significantly higher among men as compared to women for all the five countries.

\section{Noticing health warning labels on cigarette packages}

Table 2 shows current smokers who noticed HW labels on cigarette packages and thought about quitting because of HW labels. Noticing HWs varied considerably across the five countries. More than $90 \%$ of Malaysian and Romanian male smokers reported noticing HWs on cigarette packages with lower percentages found in Argentina (79.8\%), Indonesia (75.8\%) and Nigeria (56.6\%). Among women, a higher proportion of smokers in Romania (97.6\%) noticed HW labels on cigarette packages than in Argentina (89.3\%) and Indonesia (50.1\%).

The percentages of noticing HW labels on cigarette packages generally increased as age groups increased. However, the percentages decreased for older age groups among Malaysian men (65+), Nigerian men (45-64) and Romania men (45-64 and 65+). For Argentinian men, the percentages of noticing HW labels on cigarette packages decreased as age group increased till 45-64 years and increased thereafter. Among women current smokers in Romania and Argentina, the percentages of noticing HW labels on cigarette packages increased with increasing age group (up to 45-64 years age group). Whereas for Indonesian women, decreasing percentages were seen as age groups increased.

By education level, noticing HW labels on cigarette packages increased with increasing education attainment except for Romanian women where decreasing percentages were observed for current smokers with less than secondary to complete high school education.

\section{Thinking about quitting because of $\mathrm{HW}$ labels}

The percentage of male current smokers who noticed HW labels and thought about quitting was $<50 \%$ for all the five countries with the lowest among Romanian men (29.1\%). For women, it was $<40 \%$ for Argentinians, Indonesians and Romanians (Table 2).

There were great variations of the percentages of current cigarette smokers who noticed HW labels and thought about quitting by age 
Tee GH (2017) Health warnings on cigarette packages and interest in quitting: findings from five countries conducted the Global Adult Tobacco Survey in 20112012

Table 1. Percent of current manufactured cigarette smokers $\geq 15$ years old who noticed health warning labels on cigarette packages in the past 30 days.

\begin{tabular}{|c|c|c|c|c|c|c|c|c|c|c|}
\hline \multirow{4}{*}{$\begin{array}{c}\text { Demographic } \\
\text { Characteristics }\end{array}$} & \multicolumn{2}{|c|}{ Argentina } & \multicolumn{2}{|c|}{ Indonesia* } & \multicolumn{2}{|c|}{ Malaysia } & \multicolumn{2}{|c|}{ Nigeria } & \multicolumn{2}{|c|}{ Romania } \\
\hline & Male & Female & Male & Female & Male & Female & Male & Female & Male & Female \\
\hline & $\mathrm{N}=2985$ & $\mathrm{~N}=3660$ & $\mathrm{~N}=3948$ & $\mathrm{~N}=4357$ & $\mathrm{~N}=2104$ & $N=2146$ & $\mathrm{~N}=5058$ & $\mathrm{~N}=4707$ & $\mathrm{~N}=2070$ & $\mathrm{~N}=2447$ \\
\hline & $\%(95 \% \mathrm{CI})$ & $\%(95 \% \mathrm{CI})$ & $\%(95 \% \mathrm{CI})$ & $\%(95 \% \mathrm{CI})$ & $\%(95 \% \mathrm{CI})$ & $\%(95 \% \mathrm{CI})$ & $\%(95 \% \mathrm{CI})$ & $\%(95 \% \mathrm{CI})$ & $\%(95 \% \mathrm{CI})$ & $\%(95 \% \mathrm{CI})$ \\
\hline $\begin{array}{l}\text { Overall \% } \\
\text { of current } \\
\text { manufactured } \\
\text { cigarette } \\
\text { smokers }\end{array}$ & $\begin{array}{c}29.0 \\
(24.3-34.1)\end{array}$ & $\begin{array}{c}15.5 \\
(12.5-19.1)\end{array}$ & $\begin{array}{c}63.4 \\
(60.7-66.0)\end{array}$ & $\begin{array}{c}2.4 \\
(1.8-3.2)\end{array}$ & $\begin{array}{c}38.3 \\
(35.1-41.7)\end{array}$ & $\begin{array}{c}0.7 \\
(0.4-1.2)\end{array}$ & $\begin{array}{c}7.1 \\
(6.2-8.2)\end{array}$ & $\begin{array}{c}0.2 \\
(0.1-0.5)\end{array}$ & $\begin{array}{c}37.1 \\
(34.5-39.7)\end{array}$ & $\begin{array}{c}16.7 \\
(15.1-18.5)\end{array}$ \\
\hline $\begin{array}{l}\text { Overall \% } \\
\text { of current } \\
\text { manufactured } \\
\text { cigarette } \\
\text { smokers who } \\
\text { noticed health } \\
\text { warning labels in } \\
\text { the past } 30 \text { days }\end{array}$ & $\begin{array}{c}79.8 \\
(66.9-88.6)\end{array}$ & $\begin{array}{c}89.3 \\
(84.7-92.6)\end{array}$ & $\begin{array}{c}75.8 \\
(70.9-80.1)\end{array}$ & $\begin{array}{c}50.1 \\
(36.1-64.1)\end{array}$ & $\begin{array}{c}94.1 \\
(91.1-96.2)\end{array}$ & - & $\begin{array}{c}56.6 \\
(49.4-63.5)\end{array}$ & - & $\begin{array}{c}98.0 \\
(95.9-99.0)\end{array}$ & $\begin{array}{c}97.6 \\
(94.9-98.9)\end{array}$ \\
\hline \multicolumn{11}{|l|}{ Age group } \\
\hline $15-24$ & $\begin{array}{c}87.9 \\
(79.5-93.1)\end{array}$ & $\begin{array}{c}88.5 \\
(79.2-94.0)\end{array}$ & $\begin{array}{c}84.2 \\
(78.0-88.8)\end{array}$ & - & $\begin{array}{c}91.7 \\
(81.6-96.5)\end{array}$ & - & $\begin{array}{c}54.5 \\
(34.9-72.7)\end{array}$ & - & $\begin{array}{c}97.8 \\
(85.6-99.7)\end{array}$ & $\begin{array}{c}94.3 \\
(79.0-98.6)\end{array}$ \\
\hline $25-44$ & $\begin{array}{c}76.7 \\
(62.3-86.8)\end{array}$ & $\begin{array}{c}89.9 \\
(82.2-94.5)\end{array}$ & $\begin{array}{c}80.3 \\
(74.7-85.0)\end{array}$ & $\begin{array}{c}76.6 \\
(56.3-89.3)\end{array}$ & $\begin{array}{c}94.7 \\
(90.7-97.1)\end{array}$ & - & $\begin{array}{c}60.1 \\
(50.9-68.6)\end{array}$ & - & $\begin{array}{c}99.1 \\
(97.6-99.7)\end{array}$ & $\begin{array}{c}97.4 \\
(92.6-99.1)\end{array}$ \\
\hline $45-64$ & $\begin{array}{c}76.9 \\
(51.4-91.3)\end{array}$ & $\begin{array}{c}90.1 \\
(79.0-95.6)\end{array}$ & $\begin{array}{c}65.1 \\
(58.8-70.8)\end{array}$ & $\begin{array}{c}41.9 \\
(26.5-59.1)\end{array}$ & $\begin{array}{c}96.2 \\
(91.1-98.4)\end{array}$ & - & $\begin{array}{c}59.6 \\
(46.2-71.6)\end{array}$ & - & $\begin{array}{c}96.8 \\
(92.3-98.7)\end{array}$ & $\begin{array}{c}98.9 \\
(95.2-99.7)\end{array}$ \\
\hline $65+$ & $\begin{array}{c}89.6 \\
(66.7-97.4)\end{array}$ & $\begin{array}{c}84.3 \\
(63.4-94.4)\end{array}$ & $\begin{array}{c}47.4 \\
(37.1-57.9)\end{array}$ & - & $\begin{array}{c}85.6 \\
(65.0-95.0)\end{array}$ & - & - & - & $\begin{array}{c}94.4 \\
(84.3-98.1)\end{array}$ & $100(.-)$. \\
\hline \multicolumn{11}{|l|}{ Education } \\
\hline $\begin{array}{l}\text { Less than } \\
\text { primary }\end{array}$ & $\begin{array}{c}69.3 \\
(32.7-91.3)\end{array}$ & $\begin{array}{c}78.3 \\
(57.7-90.5)\end{array}$ & $\begin{array}{c}53.9 \\
(46.2-61.4)\end{array}$ & $\begin{array}{c}28.8 \\
(16.2-46.0)\end{array}$ & $\begin{array}{c}82.6 \\
(66.3-91.9)\end{array}$ & - & $\begin{array}{c}45.6 \\
(33.2-58.5)\end{array}$ & - & $\begin{array}{c}87.6 \\
(69.4-95.7)\end{array}$ & - \\
\hline $\begin{array}{l}\text { Less than } \\
\text { secondary }\end{array}$ & $\begin{array}{c}75.6 \\
(51.6-90.0)\end{array}$ & $\begin{array}{c}88.0 \\
(78.9-93.5)\end{array}$ & $\begin{array}{c}77.1 \\
(70.7-82.3)\end{array}$ & $\begin{array}{c}61.5 \\
(36.3-81.7)\end{array}$ & $\begin{array}{c}91.4 \\
(84.9-95.3)\end{array}$ & - & $\begin{array}{c}50.6 \\
(34.5-66.5)\end{array}$ & - & $\begin{array}{c}98.1 \\
(94.0-99.4)\end{array}$ & $\begin{array}{c}98.0 \\
(92.0-99.5)\end{array}$ \\
\hline $\begin{array}{l}\text { Complete high } \\
\text { school }\end{array}$ & $\begin{array}{c}84.8 \\
(70.8-92.8)\end{array}$ & $\begin{array}{c}90.4 \\
(82.6-94.9)\end{array}$ & $\begin{array}{c}83.6 \\
(78.0-88.0)\end{array}$ & - & $\begin{array}{c}96.1 \\
(91.0-98.4)\end{array}$ & - & $\begin{array}{c}65.1 \\
(53.8-74.9)\end{array}$ & - & $\begin{array}{c}98.5 \\
(94.9-99.6)\end{array}$ & $\begin{array}{c}96.8 \\
(90.2-99.0)\end{array}$ \\
\hline College or above & $\begin{array}{c}96.9 \\
(88.9-99.2)\end{array}$ & $\begin{array}{c}95.0 \\
(87.8-98.1)\end{array}$ & $\begin{array}{c}89.5 \\
(81.2-94.4)\end{array}$ & - & $100(.-)$ & - & $\begin{array}{c}77.4 \\
(50.1-92.2)\end{array}$ & - & $\begin{array}{c}99.1 \\
(93.7-99.9)\end{array}$ & $\begin{array}{c}98.8 \\
(91.5-99.8)\end{array}$ \\
\hline
\end{tabular}

$\mathrm{N}=$ Number sampled; $\mathrm{CI}=$ Confidence Interval; - = estimate based on less than 25 unweighted cases and has been suppressed

* Including kreteks

groups. The rates decreased as age increased among Indonesian, Malaysian, and Nigerian men; while the opposite direction was seen for Romanian men. In Argentina, male current smokers aged 25-44 years and those above 65 years had the highest percentages of thinking about quitting.

By education level, current smokers from upper-middle income countries (Argentina men, Malaysian men and Romania men and women) with college or above education had the lowest percentages of thinking to quit smoking. In contrast, male current smokers with less than primary education from Indonesia and Nigeria had the lowest percentages of thinking to quit smoking.

\section{Making a quit attempt in the last 12 months}

Table 3 shows the percentages of current smokers who made a quit attempt in the last 12 months by age groups and education levels. More than $40 \%$ of current smokers made a quit attempt in Malaysia (men), Argentina (men and women), Indonesia (women) and Nigeria (men). The percentages were somewhat lower among Romanian men (34.2\%) and Romanian women (38.2\%), as well as Indonesian men (29.5\%).

\section{Discussion}

HWs are an extremely cost-effective means of communicating to smokers strong and confronting messages on the health risks of smoking and are required on cigarette packages for countries that have ratified the WHO FCTC [2]. In addition, HWs also serve to educate and remind smokers to quit each time they reach for a cigarette [8]. Our study showed that higher proportions $(>90 \%)$ of current smokers noticed HWs on cigarette packages in Malaysia and Romania than in Argentina (79.8\% in men, $89.3 \%$ in women), Indonesia (75.8\% in men, $50.1 \%$ in women) and Nigeria (56.6\%). These differences might be due to the availability of different types of HWs in these five countries. Romania [11] and Malaysia [4] required PHWs on cigarette packages in 2008 and 2009 respectively. Argentina adopted PHWs in June 2012 when the data collection was underway [14]. Indonesia has just recently required PHWs in June 2014 [4]. Nigeria is the only country that has not required $\mathrm{PHWs}$ on cigarette packages even though there are textual warning labels [4].

Many studies have shown that combined HWs (i.e. graphics and text warning messages) led to increase in noticing and reading of HWs $[6,7,9,18-20]$, which might explain the differences in noticing HWs in the five countries in our study. PHWs are more effective in attracting smokers' attention than text-only HWs [21], and the information provided by PHWs can be retained for longer period of time compared to text only HWs $[9,22]$.

Apart from the lack of the use of graphics on cigarette packages in Argentina, Indonesia and Nigeria, the lower proportion of noticing HWs could be also due to warning labels in developing countries were more inferior in contents with poor color choice and package design, location and infrequent rotation of warning labels as well as information on tar/nicotine levels than those found in developed countries [23]. 
Tee GH (2017) Health warnings on cigarette packages and interest in quitting: findings from five countries conducted the Global Adult Tobacco Survey in 20112012

Table 2. Percent of current manufactured cigarette smokers $\geq 15$ years old who noticed health warning labels on cigarette packages and thought about quitting smoking as a result of noticing the warning labels by selected demographic characteristics

\begin{tabular}{|c|c|c|c|c|c|c|c|c|c|c|}
\hline \multirow{4}{*}{$\begin{array}{l}\text { Demographic } \\
\text { Characteristics }\end{array}$} & \multicolumn{2}{|c|}{ Argentina } & \multicolumn{2}{|c|}{ Indonesia* } & \multicolumn{2}{|c|}{ Malaysia } & \multicolumn{2}{|c|}{ Nigeria } & \multicolumn{2}{|c|}{ Romania } \\
\hline & Male & Female & Male & Female & Male & Female & Male & Female & Male & Female \\
\hline & $\mathrm{N}=2985$ & $\mathrm{~N}=3660$ & $\mathrm{~N}=3948$ & $\mathrm{~N}=4357$ & $\mathrm{~N}=2104$ & $\mathrm{~N}=2146$ & $\mathrm{~N}=5058$ & $\mathrm{~N}=4707$ & $\mathrm{~N}=2070$ & $\mathrm{~N}=2447$ \\
\hline & $\%(95 \% \mathrm{CI})$ & $\%(95 \% \mathrm{CI})$ & $\%(95 \% \mathrm{CI})$ & $\%(95 \% \mathrm{CI})$ & $\%(95 \% \mathrm{CI})$ & $\%(95 \% \mathrm{CI})$ & $\%(95 \% \mathrm{CI})$ & $\%(95 \% \mathrm{CI})$ & $\%(95 \% \mathrm{CI})$ & $\%(95 \% \mathrm{CI})$ \\
\hline $\begin{array}{l}\text { Overall \% } \\
\text { of current } \\
\text { manufactured } \\
\text { cigarette smokers } \\
\text { who thought about } \\
\text { quitting smoking } \\
\text { among those who } \\
\text { noticed health } \\
\text { warning labels in } \\
\text { the past } 30 \text { days }\end{array}$ & $\begin{array}{c}43.0 \\
(33.3-53.3)\end{array}$ & $\begin{array}{c}35.2 \\
(25.8-45.8)\end{array}$ & $\begin{array}{c}37.7 \\
(33.3-42.2)\end{array}$ & $\begin{array}{c}37.3 \\
(23.9-53.0)\end{array}$ & $\begin{array}{c}48.1 \\
(42.9-53.3)\end{array}$ & - & $\begin{array}{c}48.8 \\
(40.1-57.6)\end{array}$ & - & $\begin{array}{c}29.1 \\
(25.0-33.7)\end{array}$ & $\begin{array}{c}35.4 \\
(28.9-42.5)\end{array}$ \\
\hline \multicolumn{11}{|l|}{ Age group } \\
\hline $15-24$ & $\begin{array}{c}25.5 \\
(15.2-39.4)\end{array}$ & $\begin{array}{c}41.7 \\
(23.7-62.1)\end{array}$ & $\begin{array}{c}33.8 \\
(27.0-41.3)\end{array}$ & - & $\begin{array}{c}51.2 \\
(38.8-63.5)\end{array}$ & - & - & - & $\begin{array}{c}25.3 \\
(15.0-39.5)\end{array}$ & $\begin{array}{c}39.0 \\
(22.8-58.0)\end{array}$ \\
\hline $25-44$ & $\begin{array}{c}52.8 \\
(35.7-69.3)\end{array}$ & $\begin{array}{c}29.2 \\
(18.4-43.0)\end{array}$ & $\begin{array}{c}39.4 \\
(34.4-44.6)\end{array}$ & $\begin{array}{c}28.7 \\
(15.2-47.5)\end{array}$ & $\begin{array}{c}47.9 \\
(41.4-54.4)\end{array}$ & - & $\begin{array}{c}47.0 \\
(37.1-57.2)\end{array}$ & - & $\begin{array}{c}27.1 \\
(21.4-33.5)\end{array}$ & $\begin{array}{c}34.4 \\
(26.0-44.0)\end{array}$ \\
\hline $45-64$ & $\begin{array}{c}38.5 \\
(26.0-52.9)\end{array}$ & $\begin{array}{c}43.1 \\
(25.5-62.6)\end{array}$ & $\begin{array}{c}38.9 \\
(33.0-45.2)\end{array}$ & - & $\begin{array}{c}43.1 \\
(33.6-53.1)\end{array}$ & - & $\begin{array}{c}45.5 \\
(26.4-66.0)\end{array}$ & - & $\begin{array}{c}31.4 \\
(25.4-38.2)\end{array}$ & $\begin{array}{c}37.5 \\
(29.0-46.8)\end{array}$ \\
\hline $65+$ & $\begin{array}{c}74.4 \\
(57.0-86.4)\end{array}$ & $\begin{array}{c}12.2 \\
(5.0-26.7)\end{array}$ & $\begin{array}{c}24.5 \\
(14.6-38.2)\end{array}$ & - & - & - & - & - & $\begin{array}{c}48.1 \\
(33.4-63.0)\end{array}$ & $\begin{array}{c}23.4 \\
(11.0-43.0)\end{array}$ \\
\hline \multicolumn{11}{|l|}{ Education } \\
\hline Less than primary & $\begin{array}{c}43.8 \\
(23.5-66.4)\end{array}$ & $\begin{array}{c}27.8 \\
(12.8-50.4)\end{array}$ & $\begin{array}{c}29.5 \\
(23.6-36.1)\end{array}$ & - & $\begin{array}{c}43.3 \\
(26.2-62.2)\end{array}$ & - & $\begin{array}{c}43.6 \\
(26.8-62.0)\end{array}$ & - & $\begin{array}{c}28.4 \\
(13.7-50.0)\end{array}$ & - \\
\hline $\begin{array}{l}\text { Less than } \\
\text { secondary }\end{array}$ & $\begin{array}{c}51.3 \\
(36.8-65.5)\end{array}$ & $\begin{array}{c}33.7 \\
(18.0-54.0)\end{array}$ & $\begin{array}{c}37.0 \\
(30.9-43.5)\end{array}$ & - & $\begin{array}{c}51.1 \\
(42.6-59.6)\end{array}$ & - & $\begin{array}{c}57.9 \\
(40.1-73.9)\end{array}$ & - & $\begin{array}{c}30.8 \\
(23.9-38.7)\end{array}$ & $\begin{array}{c}50.0 \\
(37.9-62.1)\end{array}$ \\
\hline $\begin{array}{l}\text { Complete high } \\
\text { school }\end{array}$ & $\begin{array}{c}36.3 \\
(23.5-51.4)\end{array}$ & $\begin{array}{c}28.6 \\
(16.5-44.8)\end{array}$ & $\begin{array}{c}40.3 \\
(34.9-46.0)\end{array}$ & - & $\begin{array}{c}48.7 \\
(41.5-56.0)\end{array}$ & - & $\begin{array}{c}50.8 \\
(38.9-62.6)\end{array}$ & - & $\begin{array}{c}28.2 \\
(22.4-34.9)\end{array}$ & $\begin{array}{c}33.6 \\
(25.1-43.3)\end{array}$ \\
\hline College or above & $\begin{array}{c}29.1 \\
(7.9-66.3)\end{array}$ & $\begin{array}{c}58.4 \\
(40.3-74.6)\end{array}$ & $\begin{array}{c}39.4 \\
(30.0-49.6)\end{array}$ & - & $\begin{array}{c}39.5 \\
(25.0-56.1)\end{array}$ & - & - & - & $\begin{array}{c}27.0 \\
(20.0-35.3)\end{array}$ & $\begin{array}{c}27.2 \\
(18.1-38.7)\end{array}$ \\
\hline
\end{tabular}

$\mathrm{N}=$ Number sampled; $\mathrm{CI}=$ Confidence Interval; - = estimate based on less than 25 unweighted cases and has been suppressed

* Including kreteks

The percentages of current smokers noticing HWs were much lower for almost all educational levels in Indonesia and Nigeria where there were no PHWs on cigarette packages at the time of surveys [4]. Similar observations were found among current smokers in Argentina except those who attained college or above education. Argentina required PHWs while data collection for GATS was underway surveys $[4,14]$. PHWs are particular beneficial to illiterate people; they can see and learn from the photographs on the health risk of smoking and as the saying states "a picture is worth a thousand words". Additionally, PHWs might be more difficult to avoid than text-only warning labels due to large displays on the front and back of cigarette packages. This finding should prompt the tobacco control measures in these five countries to have large, stronger, more prominent and clear PHWs on cigarette packages so as to be able to communicate effectively across to these lower literacy populations.

Our findings showed that more youth and younger adults thought of quitting smoking as compared to the older current smokers; these finding concurred with other studies $[18,24,25]$. This difference might be due to the types of HWs in different countries. Even though Malaysia and Romania have required PHWs combined with text messages; the lower prevalence of intend to quit among Romanian smokers of different age groups could be that smoking is considered as one of the most socially acceptable health-risk behavior [11]. Other possible reason for the difference in various age groups could be the design of tobacco control programme targeting at smokers of different age groups. Youth and younger smokers may have more exposure to anti-smoking campaigns and health education through mass media as well as having less language barrier especially in lower-middle income countries.

The percentages of current smokers who made a quit attempt generally increased from less than primary education to less than secondary or complete high school and declined thereafter in our study. Hitchman et al [25] reported current smokers attained low to moderate education had higher labels impact index than higher education in four European countries. The most likely explanation is that smokers who had attained college and above education level took a more planned approach to quit smoking. Hence, HWs especially those with graphic warnings are found to be more effective among smokers with lower education to take action [23].

Borland et al [26] reported in a prospective study to examine the impact of HWs on quit attempts showed that by forgoing cigarettes in response to noticing HWs led smokers made quit attempts. HWs on cigarette packages have been shown to make smokers think about the health hazards of smoking and smoking-related health concerns; which in turn led to quit attempts. It has also been shown in populationbased study that PHW with larger size were more likely to stimulate quit intentions and subsequently making quit attempts by smokers $[20,27]$. The prevalence of quit attempts by smokers in our study varied from $29.5 \%$ in Indonesia to $47.0 \%$ in Malaysia. The prevalence of quit attempts by Argentinian smokers were much higher than Romanians even though Romania has required PHWs since 2008. This probably could be due to decrease salience and cognitive reactions that resulted in lesser behavioral response from the small PHWs (43\% front and $53 \%$ back) on cigarette packages [4] and 'wear-out effect [26] from the 
Tee GH (2017) Health warnings on cigarette packages and interest in quitting: findings from five countries conducted the Global Adult Tobacco Survey in 20112012

Table 3. Percent of current manufactured cigarette smokers $\geq 15$ years old who made a quit attempt in the last 12 months by selected demographic characteristics

\begin{tabular}{|c|c|c|c|c|c|c|c|c|c|c|}
\hline \multirow{4}{*}{$\begin{array}{l}\text { Demographic } \\
\text { Characteristics }\end{array}$} & \multicolumn{2}{|c|}{ Argentina } & \multicolumn{2}{|c|}{ Indonesia* } & \multicolumn{2}{|c|}{ Malaysia } & \multicolumn{2}{|c|}{ Nigeria } & \multicolumn{2}{|c|}{ Romania } \\
\hline & Male & Female & Male & Female & Male & Female & Male & Female & Male & Female \\
\hline & $\mathrm{N}=2985$ & $\mathrm{~N}=3660$ & $\mathrm{~N}=3948$ & $\mathrm{~N}=4357$ & $\mathrm{~N}=2104$ & $\mathrm{~N}=2146$ & $\mathrm{~N}=5058$ & $\mathrm{~N}=4707$ & $\mathrm{~N}=2070$ & $\mathrm{~N}=2447$ \\
\hline & $\%(95 \% \mathrm{CI})$ & $\%(95 \% \mathrm{CI})$ & $\%(95 \% \mathrm{CI})$ & $\%(95 \% \mathrm{CI})$ & $\%(95 \% \mathrm{CI})$ & $\%(95 \% \mathrm{CI})$ & $\%(95 \% \mathrm{CI})$ & $\%(95 \% \mathrm{CI})$ & $\%(95 \% \mathrm{CI})$ & $\%(95 \% \mathrm{CI})$ \\
\hline Overall & $\begin{array}{c}45.0 \\
(35.5-54.9)\end{array}$ & $\begin{array}{c}41.3 \\
(31.5-51.7)\end{array}$ & $\begin{array}{c}29.5 \\
(25.9-33.4)\end{array}$ & $\begin{array}{c}41.9 \\
(32.0-52.4)\end{array}$ & $\begin{array}{c}47.0 \\
(42.1-52.0)\end{array}$ & - & $\begin{array}{c}41.1 \\
(34.4-48.1)\end{array}$ & - & $\begin{array}{c}34.2 \\
(30.2-38.5)\end{array}$ & $\begin{array}{c}38.2 \\
(32.0-44.8)\end{array}$ \\
\hline \multicolumn{11}{|l|}{ Age group } \\
\hline $15-24$ & $\begin{array}{c}48.9 \\
(33.7-64.2)\end{array}$ & $\begin{array}{c}39.3 \\
(23.2-58.1)\end{array}$ & $\begin{array}{c}34.4 \\
(28.1-41.2)\end{array}$ & - & $\begin{array}{c}58.3 \\
(46.6-69.2)\end{array}$ & - & $\begin{array}{c}34.9 \\
(18.7-55.6)\end{array}$ & - & $\begin{array}{c}40.1 \\
(27.3-54.4)\end{array}$ & $\begin{array}{c}44.5 \\
(26.7-63.9)\end{array}$ \\
\hline $25-44$ & $\begin{array}{c}39.7 \\
(28.5-52.1)\end{array}$ & $\begin{array}{c}46.4 \\
(29.2-64.5)\end{array}$ & $\begin{array}{c}28.4 \\
(24.5-32.7)\end{array}$ & $\begin{array}{c}42.9 \\
(26.9-60.5)\end{array}$ & $\begin{array}{c}45.0 \\
(37.9-52.2)\end{array}$ & - & $\begin{array}{c}40.1 \\
(31.3-49.5)\end{array}$ & - & $\begin{array}{c}31.8 \\
(26.1-38.0)\end{array}$ & $\begin{array}{c}38.4 \\
(29.9-47.5)\end{array}$ \\
\hline $45-64$ & $\begin{array}{c}48.7 \\
(31.3-66.4)\end{array}$ & $\begin{array}{c}33.8 \\
(20.0-51.0)\end{array}$ & $\begin{array}{c}28.1 \\
(23.3-33.5)\end{array}$ & $\begin{array}{c}44.1 \\
(29.4-59.9)\end{array}$ & $\begin{array}{c}43.3 \\
(33.7-53.4)\end{array}$ & - & $\begin{array}{c}49.8 \\
(36.1-63.6)\end{array}$ & - & $\begin{array}{c}36.1 \\
(29.9-42.9)\end{array}$ & $\begin{array}{c}33.7 \\
(24.8-44.0)\end{array}$ \\
\hline $65+$ & $\begin{array}{c}48.5 \\
(26.2-71.4)\end{array}$ & $\begin{array}{c}48.2 \\
(25.6-71.6)\end{array}$ & $\begin{array}{c}27.5 \\
(19.4-37.5)\end{array}$ & - & $\begin{array}{c}30.2 \\
(14.4-52.6)\end{array}$ & - & - & - & $\begin{array}{c}31.9 \\
(20.4-46.2)\end{array}$ & $\begin{array}{c}49.0 \\
(27.0-71.4)\end{array}$ \\
\hline \multicolumn{11}{|l|}{ Education } \\
\hline $\begin{array}{l}\text { Less than } \\
\text { primary }\end{array}$ & $\begin{array}{c}39.9 \\
(19.3-64.7)\end{array}$ & $\begin{array}{c}45.4 \\
(25.6-66.8)\end{array}$ & $\begin{array}{c}23.3 \\
(19.3-27.9)\end{array}$ & $\begin{array}{c}31.3 \\
(19.8-45.8)\end{array}$ & $\begin{array}{c}32.9 \\
(20.9-47.7)\end{array}$ & - & $\begin{array}{c}45.6 \\
(33.3-58.4)\end{array}$ & - & $\begin{array}{c}19.2 \\
(9.5-35.0)\end{array}$ & - \\
\hline $\begin{array}{l}\text { Less than } \\
\text { secondary }\end{array}$ & $\begin{array}{c}48.0 \\
(31.6-64.9)\end{array}$ & $\begin{array}{c}53.8 \\
(35.2-71.3)\end{array}$ & $\begin{array}{c}26.0 \\
(21.3-31.3)\end{array}$ & $\begin{array}{c}51.0 \\
(31.4-70.3)\end{array}$ & $\begin{array}{c}43.6 \\
(35.5-52.0)\end{array}$ & - & $\begin{array}{c}43.9 \\
(30.4-58.4)\end{array}$ & - & $\begin{array}{c}37.7 \\
(30.7-45.3)\end{array}$ & $\begin{array}{c}35.9 \\
(24.6-49.1)\end{array}$ \\
\hline $\begin{array}{l}\text { Complete high } \\
\text { school }\end{array}$ & $\begin{array}{c}46.2 \\
(31.6-61.6)\end{array}$ & $\begin{array}{c}33.1 \\
(21.7-47.0)\end{array}$ & $\begin{array}{c}33.7 \\
(28.8-39.0)\end{array}$ & - & $\begin{array}{c}49.7 \\
(43.1-56.3)\end{array}$ & - & $\begin{array}{c}36.7 \\
(27.0-47.6)\end{array}$ & - & $\begin{array}{c}32.2 \\
(26.5-38.5)\end{array}$ & $\begin{array}{c}42.1 \\
(32.6-52.2)\end{array}$ \\
\hline $\begin{array}{l}\text { College or } \\
\text { above }\end{array}$ & $\begin{array}{c}27.0 \\
(8.0-61.2)\end{array}$ & $\begin{array}{c}33.7 \\
(20.2-50.6)\end{array}$ & $\begin{array}{c}36.8 \\
(26.9-48.0)\end{array}$ & - & $\begin{array}{c}54.8 \\
(39.8-69.0)\end{array}$ & - & $\begin{array}{c}36.2 \\
(14.8-64.9)\end{array}$ & - & $\begin{array}{c}34.0 \\
(25.5-43.7)\end{array}$ & $\begin{array}{c}39.3 \\
(25.3-55.3)\end{array}$ \\
\hline
\end{tabular}

$\mathrm{N}=$ Number sampled; $\mathrm{CI}=$ Confidence Interval; - = estimate based on less than 25 unweighted cases and has been suppressed

* Including kreteks

PHWs in Romania. On the other hand, the much lower prevalence of quit attempts among Indonesian men is consistent with the findings that small text-only HWs commanded less warning salience than PHWs combined with text messages $[6,19,20,26]$. However, Borland et al $[20,26]$ reported the probability of similar behavior change in quitrelated actions as large, prominent PHWs observed by fewer smokers who took noticed of the warning labels in countries where small textonly HWs were implemented. This might be the explanation for the higher prevalence of quit attempts by Nigerian smokers in our study.

The lower prevalence of quit attempts among older male smokers and male smokers with lower education in Indonesia, Malaysia and Romania is a cause for concern. This could be due to the acceptability of tobacco use and/or lack of smoking cessation among this population. Tobacco control programme needs to look for more innovative ways to motivate and reach out to them with the right message. Use of health warning especially PHWs must be able to communicate the risk of health effects by creating feelings of disgust, fear and regret so as to motivate these smokers through noticing, thinking about harms, thinking about quitting, making quit attempts and eventually quit smoking [20].

\section{Limitations of the study}

This study has few limitations. First, our study was based on selfreports of current smokers, thus, we were unable to rule out under reporting of smoking as well as over reporting of quitting smoking especially by female respondents from Indonesia, Malaysia and Nigeria. This is likely due to smoking by females being socially undesirable and unacceptable in these countries [28,29]. Second, the prevalence of current smoking among women is low in Malaysia [16] and Nigeria [17], thus it would not be meaningful to analyze and made association on the impact of HWs on cigarette packages among female smokers. Third, GATS core questions on the impact of HWs on cigarette packages do not differentiate text-only HWs from PHWs. Fourth, we are unable to predict whether strong HWs on cigarette packages can prevent uptake by non-smokers.

\section{Conclusion}

Majority of current smokers in the five countries were males and had noticed HWs on cigarette packages. However, less than $50 \%$ of these smokers thought about quitting smoking. In addition, only less than half of current smokers tried to quit smoking in the past 12 months. PHWs with their broad reach can serve as an important tool to systematically exposed smokers and non-smokers alike to anti-tobacco messages. PHWs are one of the "best buys" for tobacco control and should constitute part of a comprehensive tobacco control program in all countries. These five countries can use these evidence-based findings to target tobacco control interventions to increase quit rates among current smokers and prevent smoking initiation among non-smokers. Ultimately, a comprehensive tobacco program should save millions of lives by reducing morbidity and mortality caused by cigarette smoking.

\section{Acknowledgement}

We thank the Director General of Health Malaysia for his kind permission to publish this paper. The authors gratefully acknowledge Jeremy Morton and Luhua Zhao from Office on Smoking and Health, Centres for Disease Control and Prevention, Atlanta, USA for their kind assistance with this manuscript. The authors thank fieldworkers for their contributions; and survey respondents for their co-operation for making this study possible

\section{References}

1. World Health Organisation (2011). WHO report on the global Tobacco epidemic 2011: warning about the dangers of tobacco. Geneva: World Health Organisation.

2. World Health Organisation (2005). WHO Framework Convention on Tobacco Control Geneva: World Health Organisation. 
3. Hammond D, Fong GT, McDonald PW, Cameron R, Brown KS (2003). Impact of the graphic Canadian warning labels on adult smoking behaviour. Tob Control 12: 391-395. [Crossref]

4. Canadian Cancer Society (2014). Cigarette Package Warning Size and Use of Pictures: International Summary.Accessed May 2, 2015.

5. Cunningham R (2009) Gruesome photos on cigarette packages reduce tobacco use. Bull World Health Organ 87: 569. [Crossref]

6. Qin Y, Wu M, Pan XQ, Xiang QY, Huang JP, et al (2011). Reactions of Chinese adults to warning labels on cigarette packages: A survey in Jiangsu Province. BMC Public Health 11: 133

7. Hammond D, Fong GT, Borland R, Cummings KM, McNeill A, et al. (2007) Text and graphic warnings on cigarette packages: findings from the international tobacco control four country study. Am J Prev Med 32: 202-209. [Crossref]

8. Health Canada (2005). The health effects of tobacco and health warning messages on cigarette packages - Survey of adults and adult smoker: Wave 9 surveys. Prepared by Environics Research Group. Accessed May 2, 2015.

9. Pan American Health Organization (2009). Showing the truth, saving lives: the case for pictorial health warning. World No Tobacco Day, May 31, 2009. Accessed May 2,2015 .

10. Hammond D (2011). Health warning messages on tobacco products: A review. Tob Control 20: 327-337. [Crossref]

11. Ministry of Health, Romania (2011). Global Adult Tobacco Survey, Romania 2011. Accessed May 2, 2015.

12. Global Adult Tobacco Survey Collaborative Group. Global Adult Tobacco Survey (GATS): Sample Design and Sample Weight manuals, Version 2.0. Atlanta, GA: Centers for Disease Control and Prevention, 2010.

13. Global Adult Tobacco Survey Collaborative Group. Global Adult Tobacco Survey (GATS): Core Questionnaire with Optional Questions, Version 2.0. Atlanta, GA Centers for Disease Control and Prevention, 2010.

14. Global Adult Tobacco Survey, Argentina 2012. Accessed May 2, 2015.

15. Global Adult Tobacco Survey: Indonesia Report (2011). Accessed May 2, 2015.

16. Institute for Public Health (IPH) (2012). Report of the Global Adult Tobacco Survey (GATS) Malaysia, 2011. Ministry of Health.

17. Global Adult Tobacco Survey: Nigeria Country Report 2012. Accessed May 2, 2015.
18. Caixeta RB, Blanco A, Fouad H, Khoury RN, Sinha DN, et al (2011). Cigarette package health warnings and interest in quitting smoking - 14 countries, 2008-2010. MMWR Weekly 60 (20): 645-651.

19. ITC Project (2012). Health Warnings on Tobacco Packages: ITC Cross-Country Comparison Report. University of Waterloo, Waterloo, Ontario, Canada. Accessed May 2, 2015.

20. Borland R, Wilson N, Fong GT, Hammond D, Cummings KM, et al (2009). Impact of graphic and text warnings on cigarette packs: findings from four countries over five years. Tob Control 18(5): 358-364. [Crossref]

21. Noar SM, Hall MG, Franci DB, Ribisl KM, Pepper JK, et al (2015). Pictorial cigarette pack warnings: a meta-analysis of experimental studies. Tob Control 0:1-14. [Crossref]

22. Strasser AA, Tang KZ, Romer D, Jepson C, Cappella JN (2012). Graphic warning labels in cigarette advertisements: recall and viewing patterns. Am Prev medicine 43: 41-47. [Crossref]

23. Aftab M, Kolben D, Lurie P (1999). International cigarette labelling practices. Tob Control 8: 368-372. [Crossref]

24. Thrasher JF, Carpenter MJ, Andrews JO, Grey KM, Alberg AJ, et al (2012). Cigarette warning label policy alternatives and smoking-related health disparities. Am Prev Medicine 43: 590-600. [Crossref]

25. Hitchman SC, Mons U, Nagelhout GE, Guignard AM, Willemsen MC, et al (2012). Effectiveness of the European Union text-only cigarette health warnings: findings from four countries. Eur J Pub Health 22(5): 693-699. [Crossref]

26. Borland R, Yong HH, Wilson N, Fong GT, Hammond D, et al (2009). How reactions to cigarette pack health warnings influence quitting: Findings from the ITC Four-Country survey. Addiction 104: $669-675$. [Crossref]

27. Yong HH, Borland R, Thrasher JF, Thompson ME, Nagelhout GE, et al (2014) Mediational pathways of the impact of cigarette warning labels on quit attempts. Health Psychol 33(11):1410-1420. [Crossref]

28. Reimondos A, Utomo ID, McDonald P, Hull T, Suparno H, et al (2010). The 2010 Greater Jakarta Transition to Adulthood Survey. Policy Background No. 2: smoking and Young Adults in Indonesia. Accessed September 18, 2015.

29. Tee GH, Hairi NN, Hairi F (2012). Attitudes towards smoking and tobacco control among pre-clinical medical students in Malaysia. Int J Tuber Lung Dis 16(8): 1126-1128.

Copyright: (C2017 Tee GH. This is an open-access article distributed under the terms of the Creative Commons Attribution License, which permits unrestricted use, distribution, and reproduction in any medium, provided the original author and source are credited. 